Faculdade

de Ciências Econômicas UFRGS

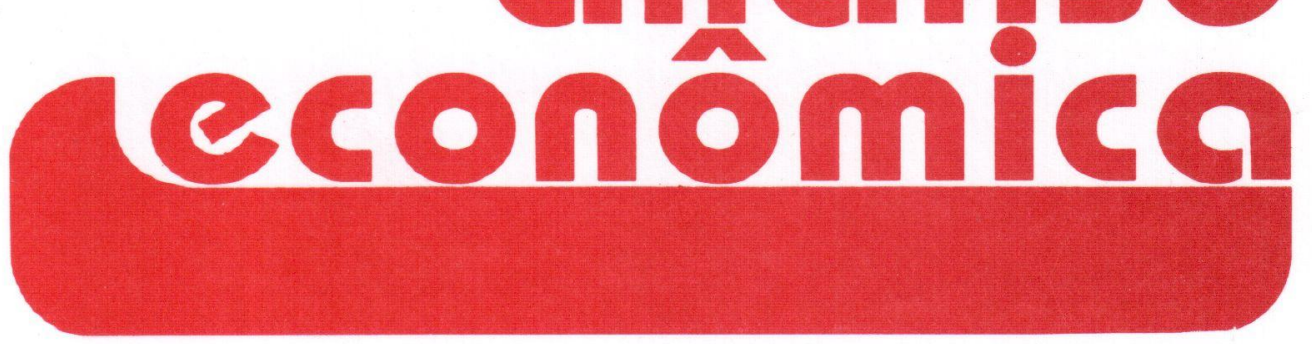

Balança Comercial e Capacidade

Produtiva da Indústria de Transformação

- Flávio Benevett Fligenspan

- Jeferson Luis Bittencourt

Breves Reflexões sobre a Relevância

da História da Teoria Econômica

- Gilberto Tadeu Lima

A Competitividade do Arroz Gaúcho

e seus Condicionantes

- Augusto M. Alvim

- Carlos G. A. Mielitz Netto

Uma Análise da Economia de Ricardo

- Liderau S. Marques Junior

A Estratégia de Substituição de

Importações Revisitada

- Alex Pereira Benício

- Joanílio Rodolpho Teixeira

The Refinements of the Orthodox Macroeconomic Theory and the Post Keynesian Theory

- Fernando Ferrari Filho

Instrumentos de Gestão Ambiental

- Jaildo Santos Pereira

- Vitor Emanuel Tavares

The Economic Implications for

Sustainable Mining

- Dina Franceschi

- James R. Kahn

Mudança Institucional e Estrutural na

Economia Brasileira do Início dos Anos Noventa

- Eduardo Simões de Almeida
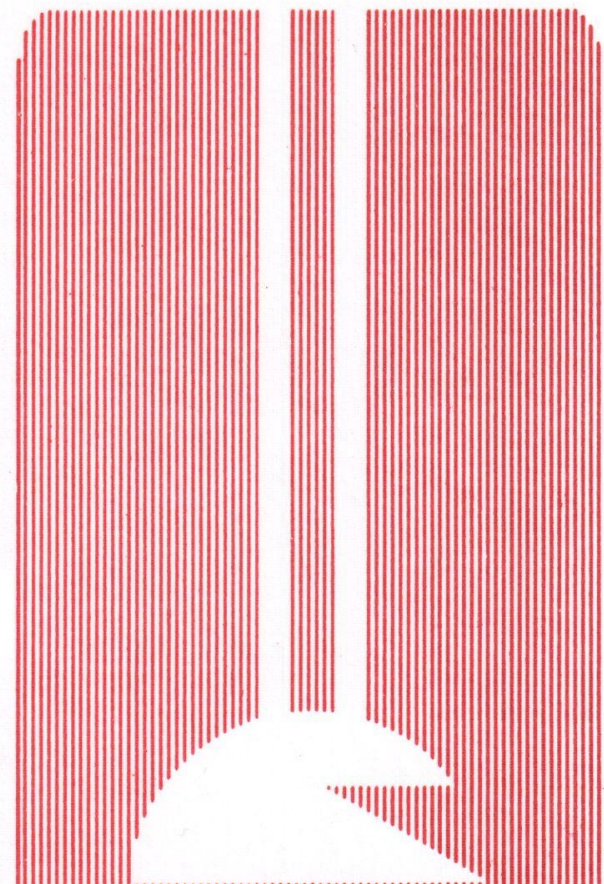

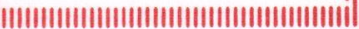
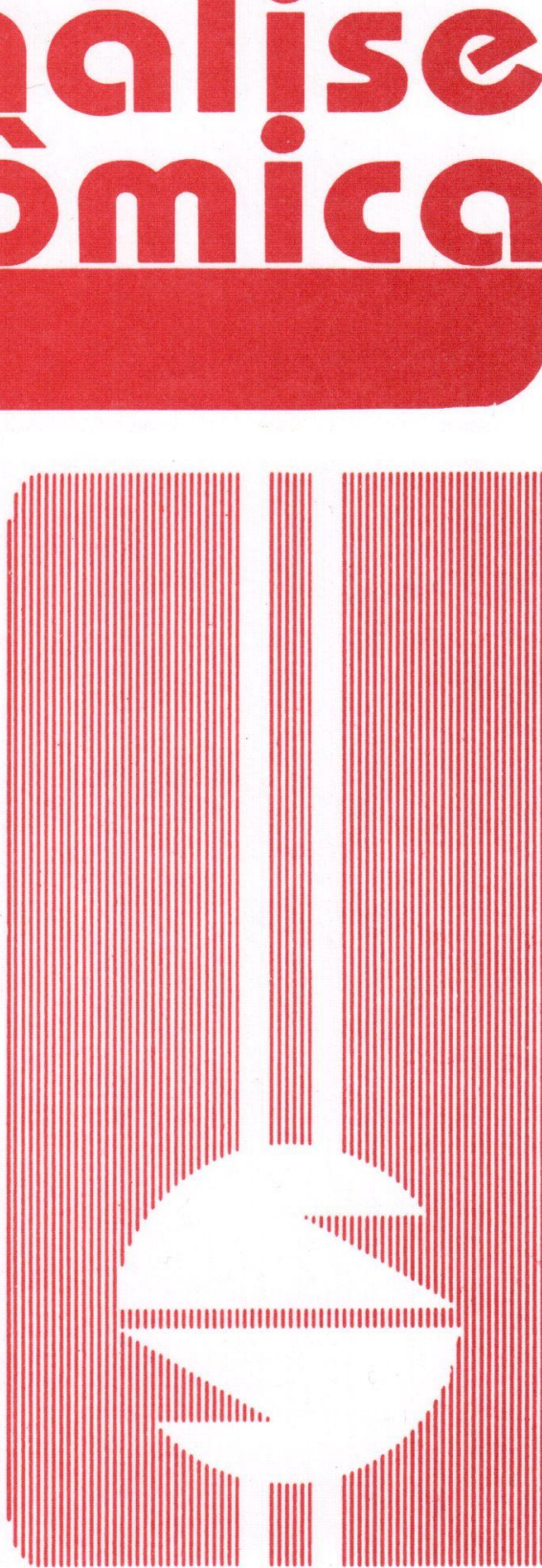
UNIVERSIDADE FEDERAL DO RIO GRANDE DO SUL

Reitora: Prof ${ }^{a}$. Wrana Maria Panizzi

FACULDADE DE CIÊNCIAS ECONÔMICAS

Diretora: Prof . Otilia Beatriz Kroeff Carrion

CENTRO DE ESTUDOS E PESQUISAS ECONÔMICAS

Diretor. Prof. Fernando Ferrari Filho

DEPARTAMENTO DE CIÊNCIAS ECONÔMICAS

Chefe: Prof. Luiz Alberto Oliveira Ribeiro de Miranda

CURSO DE PÓS-GRADUAÇÃO EM ECONOMIA

Coordenador. Prof. Marcelo Savino Portugal

CURSO DE PÓS-GRADUAÇÃO EM ECONOMIA RURAL

Coordenador. Prof. Carlos Guilherme A. Mielitz Netto

CONSELHO EDITORIAL: Achyles B. Costa, Aray M. Feldens, Carlos A. Crusius, Carlos G. A. Mielitz Netto, Eduardo A. Maldonado Filho, Eduardo P. Ribeiro, Eugênio Lagemann, Fernando Ferrari Filho, Gentil Corazza, Marcelo S. Portugal, Nali J. Souza, Otília B. K. Carrion, Paulo A. Spohr, Paulo D. Waquil, Pedro C. D. Fonseca, Roberto C. Moraes, Ronald Otto Hillbrecht, Stefano Florissi, Eleutério F. S. Prado (USP), Fernando H. Barbosa (FGV/RJ), Gustavo Franco (PUC/RJ), João R. Sanson (UFSC), Joaquim P. Andrade (UnB), Juan H. Moldau (USP), Paul Davidson (Univ. of Tennessee), Werner Baer (Univ. of lllinois).

COMISSÃO EDITORIAL: Eduardo Augusto Maldonado Filho, Fernando Ferrari Filho, Gentil Corazza, Marcelo Savino Portugal, Paulo Dabdab Waquil; Roberto Camps Moraes.

EDITOR: Gentil Corazza

EDITOR ADJUNTO: Pedro Silveira Bandeira

SECRETARIA: Fábio Sparremberger. Revisão de textos: Vanete Ricacheski.

FUNDADOR: Prof. Antônio Carlos Santos Rosa

Os materiais publicados na revista Análise Econômica são da exclusiva responsabilidade dos autores. É permitida a reprodução total ou parcial dos trabalhos, desde que seja citada a fonte. Aceita-se permuta com revistas congêneres. Aceitam-se, também, livros para divulgação, elaboração de resenhas e recensões. Toda correspondência, material para publicação (vide normas na terceira capa), assinaturas e permutas devem ser dirigidos ao seguinte destinatário:

PROF. GENTIL CORAZZA

Revista Análise Econômica - Av. João Pessoa, 52 CEP 90040-000 PORTO ALEGRE - RS, BRASIL 


\title{
INSTRUMENTOS DE GESTÃO AMBIENTAL: UMA ANÁLISE PARA O SETOR DE RECURSOS HÍDRICOS ${ }^{1}$
}

\author{
Jaildo Santos Pereira ${ }^{1}$ \\ Vitor Emanuel Tavares ${ }^{2}$
}

\section{SINOPSE}

Os processos de liberalização comercial têm recebido muitas críticas. Os ambientalistas, em especial, têm manifestado a preocupação de que estes processos se tornem uma fonte adicional de pressão sobre os recursos naturais nos paises em desenvolvimento. Ao mesmo tempo, cresce nestes países a tendência de utilização de instrumentos econômicos para a gestão ambiental, baseada na experiência de países economicamente mais desenvolvidos, na aplicação destes instrumentos. O presente trabalho busca fazer, em uma primeira etapa, uma reflexão sobre a proteção ambiental dentro do contexto desses processos de interação entre a economia e o meio ambiente, utilizando o setor de recursos hidricos como referência. Posteriormente, são apresentados e discutidos alguns instrumentos disponiveis para a política ambiental, especialmente os instrumentos econômicos. Por fim, é feita uma breve apreciação da situação brasileira quanto aos temas abordados.

Cód. AEA: 721

Palavras-chave: proteção do meio ambiente, liberalização comercial, desenvolvimento econômico.

\section{ABSTRACT}

The processes of trade liberalisation have received several criticisms. Mainly the environmentalists have manifested the concern these processes will become an additional source of pressure on natural resources in developing countries. Simultaneously, these countries are experiencing a growing tendency to use economic instruments for environmental management. Generally, their attempts are based upon the existing experience from developed countries in applying these instruments. Initially, this work looks for a reflection about the environmental protection in the context of the interaction between economy and environment based on the water resources sector. After this, some available

\footnotetext{
${ }^{1} \mathrm{O}$ primeiro autor agradece ao Prof. Nali de Jesus pela oportunidade de cursar as disciplinas Economia Regional e Desenvolvimento Econômico, que serviram de inspiração e estímulo para escrever este trabalho.

1 Doutorando em Recursos Hidricos e Saneamento Ambiental pelo Instituto de Pesquisas Hidráulicas da UFRGS - E-mail: jaildo@bigfoot.com

${ }^{2}$ Departamento de Engenharia Rural, FAEM, Universidade Federal de Pelotas Caixa Postal 354, CEP 96010-900, Pelotas, RS, Brasil. E-mail: Vtavares@ufpel.tche.br
}

\begin{tabular}{|l|l|l|l|l|}
\hline Análise Econômica & ANO 17 & N. 31 & Março/99 & p. 112-140 \\
\hline
\end{tabular}


instruments.for environmental policy are presented, especially the market based instruments. Finally, the Brazilian situation regarding these issues is briefly analysed.

AEA Code: 721

key words: environmental protection, trade liberalisation, economic development.

\section{1 - INTRODUÇÃO}

A antiga divisão do mundo em dois blocos de poder, Leste e Oeste, já não existe. Atualmente, o grande desafio e ameaça é o abismo em matéria de riqueza e saúde que separa ricos e pobres. Segundo Landes (1998) este é o maior problema e perigo com que se defronta o mundo do terceiro milênio. A outra preocupação, que acompanha de perto esta primeira, é a deterioração ambiental, e as duas estão intimamente ligadas. Na verdade, constituem um só problema, pois a riqueza gera consumo mas também lixo, produção mas também destruição. Esse lixo e essa destruição, que aumentaram muito com a produção e a renda, ameaçam o espaço em que vivemos e nos movimentamos.

A degradação excessiva dos recursos naturais tem despertado a comunidade internacional para as questões relativas ao meio ambiente e esta preocupação tem se manifestado, entre outras formas, pela realização de encontros com a participação de chefes de estados e de governos com o objetivo de firmarem acordos visando à redução da poluição. Como exemplo mais recente deste tipo de iniciativa, cita-se o congresso realizado em dezembro de 1997 em Kyoto no Japão, com o objetivo de aprovar metas para redução da emissão de gases poluentes na atmosfera.

Em nivel internacional, uma das principais preocupações ambientais é a dramática destruição de florestas tropicais. Algumas estimativas na literatura prognosticam que em países como o Brasil e Indonésia, onde estão os maiores estoques existentes de florestas tropicais no mundo, os niveis de desflorestamento anual estão por volta de 140.000 a $200.000 \mathrm{~km}^{2}$ (Amaral, 1997). Para fins de comparação, a área do Rio Grande do Sul é 267.528 $\mathrm{km}^{2}$.

As principais causas desta destruição são a conversão de florestas para a produção agrícola, pecuária e a exploração comercial da madeira. Porém, na maioria dos países, a conversão agrícola é a principal causa do processo de desflorestamento (Primo Braga, 1992).

A proteção comercial dos paises em desenvolvimento foi bastante alta até o final da década de setenta e tem diminuído desde a crise do petróleo e a crise da dívida externa no começo da década de oitenta. O Banco Mundial foi um dos principais responsáveis por essa mudança de política. A adoção de programas de ajustes estruturais em vários países em desenvolvimento utilizava a liberalização comercial como uma condição sine qua non 
para o crescimento sustentado de longo prazo e para a obtenção de empréstimos adicionais de instituições internacionais como o FMI e o BID.

A liberalização comercial foi vista por muitos especialistas como uma panacéia para os países em desenvolvimento. Segundo Amaral (1997), o impacto destas reformas seria não só de reduzir as distorções locais, mas também levaria os países a especializar-se na exportação de bens nos quais tinham uma "verdadeira" vantagem comparativa, criando desta maneira ganhos estáticos e dinâmicos a partir da abertura comercial.

Ainda segundo Amaral (1997), o problema com este argumento é que a teoria tradicional de vantagens comparativas não incorpora externalidades geradas dentro de um pais e assume que os custos sociais nacionais são iguais aos custos privados no uso de recursos naturais. As falhas de mercado produzidas por fatores como, por exemplo, a má definição de direitos de propriedade, levará um país a uma exploração de um recurso natural que não é ótima e, com a implementação de um processo de abertura comercial, esta falha institucional inicial pode ser exacerbada.

No caso da agricultura, por exemplo, seria esperado que o surgimento de blocos comerciais regionais (como o NAFTA e o MERCOSUL) e a conseqüente remoção das barreiras comerciais entre os países participantes causaria um deslocamento de atividades produtivas. Os impactos localizados deste deslocamento seriam resolvidos pela "reconversão" da agricultura nas sub-regiões afetadas. Entretanto a internalização dos custos sociais e ambientais de tal deslocamento poderia indicar que a melhor opção para a produção, a despeito das vantagens comparativas, seria sua permanência nos locais originais (May e Bonilla, 1997).

Um outro aspecto que merece destaque é o processo denominado Globalização da Economia. Com a redução da proteção comercial, o final da guerra fria e o desenvolvimento tecnológico (mais precisamente na área das comunicações), em nível de comércio internacional, as atividades econômicas passaram a se deslocar mais facilmente de um local para outro como se toda a extensão do planeta fosse um único mercado.

Neste contexto, um aspecto especialmente importante para a preservação do meio ambiente dos países em desenvolvimento é a chamada desindustrialização das economias avançadas. Com o encarecimento da mãode-obra e maior rigidez na fixação de padrões ambientais nos países desenvolvidos, muitas atividades industriais, principalmente as que geram maior quantidade de poluição (ou utilizam maiores quantidades de recursos naturais), tendem a se deslocarem para regiões onde a oferta de emprego é mais escassa e, por isso, estão dispostas a oferecer subsídios, a mão-deobra é mais barata e ainda, ou não, dispõem de uma política bem-definida de proteção do meio ambiente, ou têm seus padrões de qualidade fixados em niveis que pouco restringem seu uso. 
Mantidas estas condições, o deslocamento de atividades econômicas dos paises desenvolvidos em direção aos paises em desenvolvimento poderia implicar um significativo aumento nos níveis de degradação ambiental destes últimos. Tal sacrifício da qualidade ambiental é defendida, em alguns casos, com base em argumentos do tipo "a pior poluição é a poluição da pobreza". Entretanto este aumento da degradação ambiental poderia ser minimizado pelo uso de barreiras não-tarifárias, visando criar obstáculos para a importação de produtos em cuja produção sejam utilizados produtos e técnicas prejudiciais ao meio ambiente.

As relações entre comércio e qualidade ambiental vêm sendo discutidas já há algum tempo. Entretanto o surgimento de propostas de incentivo às práticas menos nocivas ao ambiente, mediante a adoção de barreiras não-tarifárias intensificou os debates e o surgimento de controvérsias. Nos países em desenvolvimento, constantemente acusados de negligência no tratamento da questão ambiental, tal prática tem sido interpretada como um artifício para restringir seu acesso ao mercado. Esta prática pode ser criticada, também, sob o ponto de vista da redução da renda dos países menos desenvolvidos, em função do menor volume de exportações. Este diferencial de renda poderia ser utilizado na aquisição ou desenvolvimento de tecnologias que permitissem o uso de práticas ambientalmente mais adequadas.

Sendo assim, o uso de barreiras não-tarifárias não deveria se dar com base em um simples banimento de produtos, mas sim na forma do estabelecimento de metas ambientais a serem atingidas ao longo de um cronograma factível, acompanhado de programas de incentivo à transferência tecnológica.

\section{2 - A ÁGUA NO MUNDO}

Nos últimos anos, a água tem sido gradativamente reconhecida como um recurso escasso em escala mundial (UNCED, 1992). Entretanto deve-se fazer distinção entre as duas causas de sua escassez: as limitações qualitativas no uso de água devido à poluição, por exemplo, e as limitações quantitativas devido às condições climáticas, à demanda crescente ligada ao aumento populacional, ao desenvolvimento econômico e ao seu uso ineficiente. Essas duas causas não se excluem, mas requerem mecanismos de gestão diferentes ou, pelo menos, complementares.

Segundo Kemper (1997), a escassez de água devido à poluição é um problema do norte e do centro da Europa, onde as chuvas são abundantes e a evapotranspiração é baixa, e onde os usos industrial e agrícola poluem os recursos hídricos de superfície e subterrâneos. A Dinamarca e a Holanda são exemplos de países onde os lençóis subterrâneos foram poluídos pela 
atividade agroindustrial. A Polônia e a Alemanha são países onde a água de superfície também está poluída.

No caso brasileiro, as regiões Sul e Sudeste, onde está concentrado mais da metade do parque industrial brasileiro, a escassez de água é basicamente devido à poluição (vide o exemplo do rio Tietê, em São Paulo). A Região Nordeste, onde está concentrada $29 \%$ da população total do Brasil, tem um problema histórico de escassez de água basicamente devido às condições climáticas. Diferentemente das Regiões Sul e Sudeste, que apresentam bons índices pluviométricos e alarmantes problemas de poluição e da Região Nordeste, que apesar de ter menores problemas de contaminação apresenta condições climatológicas desfavoráveis, a Região Norte é a região do Brasil que possui os maiores índices climatológicos e a menor população, daí a preocupação mundial com a preservação desta que pode vir a ser uma reserva estratégica não só para o Brasil, mas como para o mundo.

\section{1 - A distribuição de água no mundo}

A desigualdade da distribuição de água sobre a terra depende de fatores físicos (climáticos) e humanos (densidade populacional). Os fatores físicos podem ser considerados como o lado da disponibilidade do recurso (oferta) e os fatores humanos como a demanda.

Segundo OIA (1994), nove "gigantes" mundiais de água possuem $60 \%$ do total dos recursos hídricos disponiveis no planeta, conforme ilustra o Quadro 1.

Quadro 1 - Os nove "gigantes" de água no mundo

\begin{tabular}{|l|c|}
\hline \multicolumn{1}{|c|}{ País } & Recursos Hidricos $\left(\mathrm{km}^{3} / \mathrm{ano}^{\prime} / \mathrm{km}^{2}\right)$ \\
\hline Brasil & 5670 \\
Rússia & 3904 \\
China & 2880 \\
Canadá & 2856 \\
Indonésia & 2530 \\
USA & 2478 \\
India & 1550 \\
Colômbia & 1112 \\
Zaire & 1020 \\
Comunidade Econômica Européia & 816 \\
\hline
\end{tabular}

Fonte: World Resources Institute - Washington (1991) apud OIA (1994)

Para corrigir a incidência das grandes diferenças de densidade de população, os recursos hídricos disponíveis em cada país podem ser ajustados a suas respectivas populações, expressando-se em número de $\mathrm{m}^{3} /$ ano por habitante. Dessa forma, observa-se que os países mais importantes em recursos hídricos por habitante estão entre os equatoriais ou nórdicos mais 
chuvosos e/ou pouco povoados: O recorde mundial estaria no Suriname (2 milhões $\mathrm{m}^{3} /$ hab/ano) e Islândia, o recorde da Europa $\left(708.000 \mathrm{~m}^{3} / \mathrm{hab} / \mathrm{ano}\right)$.

O outro extremo, mais pobre em recursos hídricos por habitante, se encontra nos países áridos ou insulares e/ou muito povoados, com recurso global limitado. O Quadro 2 apresenta os doze paises mais pobres em recursos hídricos por habitante e destaca-se que oito destes são árabes.

Quadro 2 - Os doze países mais pobres em recursos hídricos por habitante

\begin{tabular}{|l|c|}
\hline \multicolumn{1}{|c|}{ Pais } & Recursos Hidricos ( $\left.\mathrm{m}^{3} / \mathrm{ano} / \mathrm{hab}\right)$ \\
\hline Kuwait & (Valor muito baixo) \\
Malta & 50 \\
Catar & 62.5 \\
Bahamas & 87 \\
Baherein & 119 \\
Yemen & 126 \\
Arábia Saudita & 191 \\
Libia & 194 \\
Antilhas Holandesas & 231 \\
Emirados Árabes Unidos & 231 \\
Singapura & 234 \\
Jordânia & 313 \\
\hline
\end{tabular}

Fonte: OIA (1994)

$\mathrm{Na}$ situação extrema também se encontram a maioria dos paises desenvolvidos da Zona Temperada: França $=3.360 \mathrm{~m}^{3} / \mathrm{ano} / \mathrm{hab} ; \mathrm{CEE}=2.530$ $\mathrm{m}^{3}$ /ano/hab.

Os valores apresentados nos quadros anteriores podem ser considerados demasiadamente globais mas, apesar disso, servem para ilustrar a distribuição desigual de água no planeta. Uma abordagem mais criteriosa deve considerar as diferenças internas de cada país, por exemplo, diferenças hidrogeológicas e climáticas e ainda as diferenças da qualidade da água disponível.

\section{2 - Os principais usos de água}

A demanda de água, assim como a disponibilidade, é desigual no mundo e depende de três fatores:

- Clima - em uma grande parte do mundo, onde existe déficit hídrico (zonas áridas, semi-áridas ou mediterrâneas), a produção agrícola está subordinada, principalmente, à irrigação. A demanda de água para irrigação predomina sobre todas as demandas e aumenta consideravelmente a demanda global de água. A aridez do clima aumenta consideravelmente o consumo de água das reservas por evaporação. Dessa forma, os paises localizados nas zonas áridas e semi-áridas são duplamente penalizados: pela escassez dos recursos e pelo aumento da demanda de água; 
- Tamanho da população - ainda que as demandas efetivas por habitantes variem consideravelmente, particularmente em função do nível de urbanização;

- Grau de desenvolvimento sócio-econômico - um alto grau de desenvolvimento implica maiores demandas de água.

Quadro 3 - Utilização de Água no Mundo

\begin{tabular}{|c|c|c|c|c|c|c|}
\hline Espaços geológicos & Disponibilidade & & emandas $\mathrm{De}$ & Água (anos & 80) & \\
\hline (Grupo de Paises) & Hídrica & Total & Distribui & รão entre os & usos $(\%)$ & Líquido Total \\
\hline & $\left(\mathrm{km}^{3} / \mathrm{ano}\right)$ & $\left(\mathrm{km}^{3} / \mathrm{ano}\right)$ & Doméstico & $\begin{array}{l}\text { Agricultura } \\
\text { (Irrigaçăo) }\end{array}$ & $\begin{array}{c}\text { Indústria e } \\
\text { Energia }\end{array}$ & $\left(\mathrm{km}^{3} / \mathrm{ano}\right)$ \\
\hline $\begin{array}{l}\text { Europa Ocidental, } \\
\text { Nórdica e Mediter- } \\
\text { rânea } \\
\text { (E.E.C. + A.E.L.E) }\end{array}$ & 1800 & 250 & 17 & 36 & 47 & 70 \\
\hline $\begin{array}{l}\text { Leste Europeu e } \\
\text { ex- URSS }\end{array}$ & 5200 & 430 & 8 & 63 & 29 & 185 \\
\hline $\begin{array}{l}\text { América do Norte } \\
\text { (USA e Canadá) }\end{array}$ & 5560 & 503 & 12 & 39 & 49 & 130 \\
\hline $\begin{array}{l}\text { América Latina e } \\
\text { Caribe }\end{array}$ & 11450 & 185 & 13 & 78 & 9 & 120 \\
\hline $\begin{array}{l}\text { Mundo Árabe, } \\
\text { África do Norte e } \\
\text { Oriente Médio }\end{array}$ & 590 & 220 & 7 & 90 & 3 & 150 \\
\hline $\begin{array}{l}\text { África do Sul } \\
\text { Saara } \\
\text { (com Madagascar) }\end{array}$ & 3930 & 57 & 18 & 78 & 4 & 40 \\
\hline $\begin{array}{l}\text { Sub-Continente } \\
\text { Índio } \\
\text { e Sudeste da Ásia }\end{array}$ & 7550 & 750 & 4 & 93 & 3 & 500 \\
\hline $\begin{array}{l}\text { China (com Mongó- } \\
\text { lia e } \\
\text { Coréia do Norte) }\end{array}$ & 2750 & 460 & 7 & 86 & 7 & 300 \\
\hline $\begin{array}{l}\text { Japão e Tigres } \\
\text { Asiáticos }\end{array}$ & 640 & 130 & 18 & 53 & 29 & 45 \\
\hline Austrália e Oceania & 840 & 20 & 22 & 70 & 8 & 10 \\
\hline
\end{tabular}

Fonte: OIA (1994)

A demanda de água por habitante varia notavelmente. A média mundial é da ordem de $600 \mathrm{~m}^{3} / \mathrm{hab} / \mathrm{ano}$ e os extremos flutuam entre 50 e 2000 $\mathrm{m}^{3}$ /hab/ano.

A distribuição de água entre os tipos de usos depende do nível sócioeconômico do pais (capacidade de mobilizar recursos e tipo de atividade que emprega estes recursos) e também dos fatores naturais anteriormente citados (clima e hidrogeologia). 
Os usos da água podem ser classificados em quatro grupos: domésticos, agricolas (irrigação), industriais e hidroelétricos. O quadro 3 apresenta um panorama da distribuição da água no mundo, entre os principais usos.

\section{3 - O empobrecimento dos recursos}

Assim como ocorreu com o petróleo, alvo permanente de disputas financeiras e constante estopim de guerras, a água tem tudo para virar a década como a commodity do novo milênio. A explosão desordenada dos anos 80 transpôs para metrópoles emergentes em todo mundo, como São Paulo, Cidade do México e Beijing, uma preocupação até então comum apenas a países do Oriente Médio e da Ásia: a iminência da escassez de água em condições de uso. Mesmo em um país como o Brasil, o ouro negro e escasso representado pelo petróleo tende a ser destronado em importância por mananciais de água de qualidade crescentemente ameaçada (Amanhã, 1997).

Devido à escassez de água, seja pelo aspecto quantitativo (a quantidade não é suficiente para suprir a demanda) ou pela má qualidade, a água apresenta uma curva de custo marginal crescente. Existe projeção que indica que a conta da água deverá, possivelmente na próxima geração, superar a conta de energia elétrica. Em alguns países do mundo, o custo da água já supera o do petróleo (Amanhã, 1997).

O crescimento demográfico aumenta a pressão sobre os recursos hídricos. O caso da China ilustra bem esta situação. Este país concentra um quinto da população mundial, porém tem menos de um décimo de toda água existente no planeta em terra firme. Nesta pais, $35 \%$ dos poços artesianos já secaram (Kemper, 1991).

\section{3 - A POLÍTICA AMBIENTAL}

Em 1990, no final da Década Internacional de Suprimento de Água e Saneamento, os resultados de anos de atividades de desenvolvimento no setor de recursos hídricos foram frustrantes. O crescimento contínuo da população ameaçava superar as possibilidades físicas e financeiras de aumentar a oferta de água, ao mesmo tempo em que surgiam grandes evidências de que a água estava sendo usada de maneira ineficiente em todos os setores.

Em 1991, a Consulta Informal de Copenhague pedia que a água fosse reconhecida não apenas como bem social, mas também como bem econômico, isto é, como um recurso escasso com valor econômico distinto em cada um de seus usos (Nordic Freswater Iniative apud Kemper, 1991). Esta nova percepção, que mais tarde viria a ser refletida na Declaração de Dublin, na Agenda 21 e no documento sobre a Política de Gestão dos Re- 
cursos Hidricos do Banco Mundial, pede a busca e a implantação de novos mecanismos que aumentem a eficiência na alocação e no uso dos recursos hídricos (World Bank, 1993).

A conseqüência de se aceitar a água como recurso econômico é que os usuários da água ficam suscetíveis aos incentivos que são dados ao uso. Um recurso econômico é, por definição, um recurso escasso e quando um recurso é escasso, ele não será suficiente para satisfazer uma demanda ilimitada. Portanto, devem-se tomar certas decisões quanto a sua alocação, baseandomse, entre outras coisas, em principios econômicos, administrativos ou políticos.

Não importa a maneira pela qual os recursos hídricos sejam alocados, os usuários perceberão algum tipo de incentivo. Se receberem um grande volume de água barata vão usá-la em abundância. Se receberem a água irregularmente, tentarão retirar mais do que precisam e irão armazená-la para uso posterior. Se a água for cara, eles tentarão usá-la de forma mais eficiente.

O problema desta última alternativa diz respeito à má distribuição de renda que existe, sobretudo nos países em desenvolvimento, o que poderia induzir os usuários de menor renda a tentarem utilizar água de qualidade inferior o que provocaria diversos problemas relacionados com a saúde e novamente colocaria em evidência a eficiência da política de gestão.

Definida a necessidade de aplicação de uma política ambiental, a questão seguinte é sobre a escolha de instrumentos que sejam capazes de preservar o meio ambiente, preferencialmente, sem comprometer o crescimento econômico.

Os instrumentos de controle do uso dos recursos naturais podem ser classificados, segundo sua natureza, em sistemas de regulamentação de comando e controle e instrumentos econômicos. Ambos serão discutidos a seguir.

\section{1 - Comando e controle}

Os instrumentos de comando e controle correspondem ao sistema em que o poder público estabelece os padrões e monitora a qualidade ambiental, regulando as atividades e aplicando sanções e penalidades, via legislação e normas (Leal, 1997). A principal característica da política de "comando e controle" é que a mesma, em base legal, trata o poluidor como "ecodelinquiente" e, como tal, não the dá chance de escolha: ele tem que obedecer a regra imposta, caso contrário se sujeita a penalidades em processos judiciais ou administrativos (Almeida, 1997). O caso de não cumprimento da obrigação é, com bastante freqüência, penalizado com aplicação de multas. 
Essa mesma característica é considerada, para alguns, uma grande desvantagem e, para outros, uma importante vantagem. A desvantagem é que os poluidores não têm liberdade para selecionar e promover os ajustes no tempo que lhes convier; não é regra justa, uma vez que não leva em consideração as distintas situações dos agentes individuais para cumprir a obrigação. A vantagem é que estes instrumentos têm uma elevada eficácia ecológica, uma vez fixada a norma (de modo apropriado), será cumprida (se os poluidores não violarem a lei).

Entre as desvantagens da política de "comando e controle", os econo" mistas geralmente apontam:

- economicamente são ineficientes porque não consideram as diferentes estruturas de custos dos agentes privados para redução de poluição;

- têm custos administrativos muito elevados, pois envolvem o estabelecimento de normas e/ou especificações por agências oficiais, bem como um forte esquema de fiscalização;

- criam barreiras à entrada de novas empresas; a concessão de licenças não-comercializáveis tende a perpetuar a estrutura de mercado existente;

- após atingir o padrão ou que a licença seja concedida, o poluidor não é encorajado a introduzir novos aprimoramentos tecnológicos (antipoluição);

- podem sofrer influência de determinados grupos de interesse.

Os instrumentos de comando e controle apresentam diferentes niveis de flexibilidade e podem ser considerados nas seguintes categorias:

\subsection{1 - Normas sobre as emissões}

Esta politica consiste em impor ao poluidor condições sobre o teor de seus lançamentos e, eventualmente, sobre o volume (Ramos, 1996). Sendo permitido ao poluidor a escolha da técnica ou tecnologia utilizada para alcançar os padrões estabelecidos, esta pode ser considerada a forma mais flexivel da política de comando e controle. As normas são preferiveis quando se está em presença de catástrofes ambientais ou se um risco imediato de tal catástrofe existe.

Entretanto diversos autores alertam para alguns inconvenientes na aplicação deste instrumento. Isto se torna mais evidente quando os poluidores têm custos marginais de despoluição diferentes. Como conseqüência, uma dada redução da poluição é obtida a custos mais elevados que no caso de taxas uniformes por poluente (os quais permitem igualar os custos marginais de despoluição para todos os poluidores) (Cánepa, 1995, Pereira, 1996, Ramos, 1996). 


\subsection{2 - Prescrições tecnológicas}

Trata-se de impor uma técnica particular ao poluidor, isto é, impor (ou interditar) o emprego de certos inputs ou de certos processos de fabricação ou ainda certas técnicas de tratamento. Esta política pode ser subdividida em três grupos:

- Controle de equipamentos - exigência de instalação de equipamentos antipoluição (por exemplo, filtros); obrigatoriedade de uso de tecnologias "limpas" já disponíveis;

- Controle de processos - exemplo: exigência de substituição de um óleo combustível com alto teor de enxofre, empregado como insumo, por um outro, com baixo teor;

- Controle de produtos - visa à geração de produtos "mais limpos", estabelecendo normas para produtos cujo processo de produção ou consumo final acarrete alguma forma de poluição. Exemplos: especificação da quantidade de agrotóxicos em produtos agrícolas e proibição de carros com baixo desempenho energético.

Um tipo menos difundido de prescrição tecnológica consiste em solicitar aos poluidores aplicar a melhor tecnologia praticável (best praticable tecnology - BPT) ou a melhor tecnologia disponivel (best available tecnology - BAT) em data futura.

Para que a aplicação da prescrição tecnológica seja um instrumento eficaz, é necessário que não exista dúvida quanto à solução mais eficaz para atingir a norma, caso contrário, a exigência que uma tecnologia específica seja adotada será certamente fonte de má alocação de recursos.

Outro inconveniente desta política é que a quantidade real de descargas para qual o processo exigido foi projetado pode ser ultrapassada, ou o equipamento que atinge certos padrões pode ser modificado pelo utilizador. Excetuando a proibição ou restrição de atividades, esta é, provavelmente, a forma menos flexivel das políticas de comando e controle.

\subsection{3 - Proibição total ou restrição de atividades}

A proibição total ou restrição de atividades a certos periodos do dia, áreas, etc., por meio de: concessão de licenças (não-comercializáveis) para instalação e funcionamento; fixação de padrões de qualidade ambiental em áreas de grande concentração de poluentes; e zoneamento.

Tais medidas têm por finalidade um controle espacial (e/ou temporal) das atividades dos agentes econômicos, procurando resguardar a capacidade de absorção do meio. Um exemplo de aplicação deste tipo de política é o rodízio de automóveis na cidade de São Paulo. 


\subsection{4 - Controle do uso de recursos naturais}

Neste caso o controle do uso de recursos naturais é realizado por intermédio de fixação de cotas (não-comercializáveis) de extração, por exemplo, para a extração de madeiras o órgão ambiental pode exigir uma cotaárvore de reflorestamento para cada unidade de extração.

\section{2 - Instrumentos econômicos}

Segundo Almeida (1997), não há dúvida de que a teoria econômica que oferece um suporte imediato para a discussão de instrumentos de política ambiental é a microeconomia neoclássica, especificamente seu conceito de externalidades.

Fazer valer o princípio poluidor-pagador, aplicando instrumentos econômicos, em especial, as taxas ambientais, que internalizem as externalidades no processo de decisão do agente agressor do meio ambiente, é a orientação vencedora no debate internacional sobre política ambiental. A dificuldade seguinte está na própria definição de instrumento econômico.

Supostamente, um instrumento econômico seria tido como econômico uma vez que afetasse o cálculo de custos e benefícios do agente poluidor, influenciando suas decisões, no sentido de produzir uma melhoria na qualidade ambiental (Almeida, 1997).

Observa-se que a maioria das taxas já aplicadas em vários países, por serem fixadas em níveis muito baixos, não chegam a ter impacto significativo sobre os custos e benefícios do poluidor a ponto de induzir uma alteração no seu comportamento e, seguindo à risca a definição anterior, não poderiam ser enquadrados como instrumentos econômicos.

Outra forma de se referir ao instrumento econômico é tratar-se de um mecanismo atrelado a um componente monetário, que age via preço (pelo uso ou abuso do meio ambiente) e não via quantidade. Dessa maneira, seriam excluidas as licenças de emissão negociáveis, pois são cotas (físicas) que os poluidores podem negociar entre si.)

A noção de instrumento econômico passou a significar diferentes coisas em diferentes contextos, conforme as distintas visões sobre o que é economia (OECD, 1989 apud Almeida, 1997). Diante disso, destacam-se, a seguir, os principais instrumentos reconhecidos pelo senso comum como sendo econômicos.

\subsection{1 - Sistemas de cobrança}

Consiste em cobrar um valor igual aos custos marginais da contaminação ao nível ótimo de produção. O poluidor assumirá o custo externo de sua 
poluição na forma de uma taxa, que obviamente tratará como custo privado. Diz-se então que o custo externo foi "internalizado".

A aplicação deste instrumento como política de gestão ambiental cumpre, simultaneamente dois papéis: um instrumento de financiamento da luta coletiva contra a poluição e um incentivo que conduz o poluidor a modificar seu comportamento, no caso em que tal ação é menos dispendiosa que pagar a taxa.

Na prática, entretanto, não se aplica a taxa ambiental tal qual prescrita pela teoria, uma vez que a taxa "ótima" exige o conhecimento da função de danos do agente poluidor (valor monetário do dano ambiental provocado por unidade de poluição emitida - o custo econômico das externalidades), um problema teórico/prático não superado. Segundo OECD (1989) apud Almeida (1997), os decisores fixam valores das taxas aos níveis que eles consideram suficiente para atingir seus objetivos políticos.

Os economistas da corrente principal têm adotado, de forma quase consensual, esta visão mais flexível do papel das taxas, que, provavelmente cedendo aos fatos, passam a propor sistemas mistos taxa-padrão como opção de política ambiental.

Os que defendem a taxa, como o meio mais eficaz de se atingir um padrão previamente estabelecido, tomam, como argumento favorável, a situação das firmas em melhores condições, que empreendem esforços adicionais para reduzir sua poluição para além do exigido pelo padrão, enquanto seus custos de controle estiverem abaixo das despesas com as taxas e que, dessa forma, conseguem oferecer incentivos dinâmicos para inovações tecnológicas.

Uma outra hipótese que pode ocorrer é a situação de uma concentração de firmas altamente poluidoras e em piores condições (financeiras e/ou tecnológicas). Neste caso, o uso de taxa combinada a padrão resultaria num padrão médio de poluição acentuadamente aquém do considerado aceitável. Nesta hipótese, um número maior de firmas optaria por pagar as taxas e continuar poluindo sem atingir o padrão fixado, aumentando os riscos cumulativos de danos ambientais

Assim mesmo, a proposta vencedora de política ambiental é essa combinação taxa-padrão, em que a taxa deixa de ter seu valor determinado pelo dano marginal causado, podendo assumir distintas bases de cálculo, por exemplo, taxas cobradas proporcionalmente às emissões de poluentes. A seguir apresentam-se os principais tipos de taxas, já bastante difundidos em países avançados.

- Taxas sobre efluentes - a cobrança é efetuada por unidade de lançamento de determinados poluentes no meio (água, ar, solo). Consiste num tratamento caso a caso, que não diferencia as fontes poluidoras de acordo com seus respectivos danos ambientais, mas pela 
quantidade e/ou qualidade dos poluentes lançados. Nesse sentido, não exerce estímulos à realocação espacial de atividades poluidoras, uma vez que a taxa paga por lançamento de poluente é a mesma, quer a fonte se localize num grande centro industrial (altamente poluído) ou numa região cujo meio ambiente apresente uma maior capacidade de absorção;

- Taxas sobre o usuário - é o caso dos pagamentos pelos custos de tratamento público ou coletivo de efluentes, mais precisamente, são tarifas cobradas uniformemente ou diferenciadas de acordo com a quantidade de efluentes tratados;

- Taxas sobre produtos - essas incidem sobre o preço de produtos que geram poluição no momento de sua produção e/ou consumo ou para os quais tenha sido implementado um sistema de remoção. Podem ser baseadas em especificações do produto (exemplo: sobre conteúdo de enxofre em óleos minerais) ou no produto como um todo (sobre óleo mineral);

- Diferenciação de taxas - acarreta em preços mais favoráveis para produtos não-ofensivos ao meio ambiente e vice-versa. Este instrumento se assemelha às taxas sobre produtos, sỏ que normalmente é neutro em relação às receitas públicas, enquanto que essas taxas têm como objetivo adicional um aumento de arrecadação;

- Sistema de depósito reembolsável ou consignação - este sistema funciona através da cobrança de uma taxa sobre o produto, no ponto de compra, com posterior reembolso da taxa, caso a embalagem do produto seja devolvida, ou entregue em algum local preestabelecido para reciclagem, ou disposição segura. Um exemplo bem-conhecido é o depósito pago por vasilhames de bebidas (OCDE, 1994a). O uso de sistemas de consignação para embalagens de produtos potencialmente poluidores, como pesticidas, por exemplo, é apontado por Martinez Junior e Braga Junior (1997) como uma importante alternativa para o controle da poluição hídrica.

\subsection{2 - Subsídios}

Este instrumento de politica ambiental tem propriedades semelhantes às da taxa, no sentido em que fornece o mesmo incentivo para reduzir as emissões, porém com a vantagem de gerar menos oposição: as empresas são evidentemente mais receptivas a medidas que financiem os custos de controle de poluição que aquelas que jogam a carga sobre elas.

Pode-se afirmar que existe uma equivalência em termos das condições de primeira ordem entre taxas e subsídios, entretanto existem também algumas assimetrias, (a mais evidente é o efeito sobre o lucro) que influenciam diferentemente as decisões de entrada e saída das firmas. 
Os principais tipos de subsídios são:

- Subvenções - formas de assistência financeira não-reembolsáveis, oferecidas para poluidores que se prontifiquem a implementar medidas para reduzir seus niveis de poluição;

- Empréstimos subsidiados - empréstimos a taxas de juros abaixo das de mercado oferecidos a poluidores que adotem medidas antipoluição;

- Incentivos fiscais - depreciação acelerada ou outras formas de insenção ou abatimentos de impostos em caso de serem adotadas medidas antipoluição.

Todos os tipos de subsídios apresentados acima são oferecidos pelo governo aos agentes econômicos que adotem medidas de redução da degradação ambiental.

Uma forma alternativa de subsídio, na forma de subvenção, pode ser paga pelo governo à vítima da poluição, para compensar os danos que the foram causados. Neste caso, o subsídio, cujos recursos podem ser provenientes de uma taxa ambiental aplicada sobre a atividade poluidora, tem um caráter puramente compensatório e não reduz o nivel de poluição.

Enquanto alguns tipos de subsídios podem ser uma forma de incentivo ao combate dos problemas ambientais, outros se tornam promotores de práticas economicamente ineficientes e prejudiciais ao ambiente. Alguns programas de incentivo à agricultura, por exemplo, foram responsáveis por um aumento na conversão de banhados e pelo uso excessivo de pesticidas e fertilizantes químicos, bem como de mecanização intensiva, provocando aumento nas taxas de erosão e poluição hídrica.

Assim sendo, a redução de subsídios governamentais também pode ser um instrumento econômico da política ambiental, como forma de corrigir algumas distorções do mercado.

\subsection{3 - Seguros ambientais}

Almeida (1997) apresenta este instrumento de política ambiental como um mecanismo que procura incorporar critérios de incertezas ambientais ao sistema de mercado. Na verdade trata-se de uma extensão do "princípio poluidor-pagador" no qual o poluidor paga também pelas incertezas.

Costanza apud Almeida (1997) sugere que, em acréscimo às cobranças diretas por danos ambientais conhecidos, uma empresa deveria ter a obrigação de depositar um seguro igual à melhor estimativa atual dos maiores danos ambientais possíveis no futuro, mantido em fundos com rendimentos. Caso a empresa pudesse comprovar que os danos em potencial não ocorreram ou não ocorreriam, a importância seria devolvida, caso os danos ocorressem, a quantia seria utilizada para recuperar o ambiente degradado e/ou compensar as vítimas da poluição. 


\subsection{4 - Permissões de emissão negociáveis (PEN)}

Através deste instrumento pode-se criar artificialmente um "mercado para poluição", permitindo aos agentes comprar ou vender direitos (cotas) de poluição de fato ou potencial. Este mesmo instrumento recebe outras denominações, por exemplo, licenças de emissão comercializáveis, certificados de redução de emissão e direitos de poluição. Para evitar a falsa interpretação de que as pessoas possam adquirir direitos de poluir, o que certamente provocaria a ira dos ambientalistas, o uso da denominação permissões de emissão negociáveis parece ser mais adequado.

As permissões de emissão negociáveis são um instrumento de merca. do que atua via quantidade e não via preço (custo) de poluição, contornando uma grande dificuldade das taxas, que é justamente determinar e manter o seu valor de modo a garantir a sua eficiência econômica e eficácia ecológica.

Um exemplo que facilita a compreensão do funcionamento deste instrumento de política ambiental: o governo fixa um padrão de total de toneladas de dióxido de enxofre por ano, total este dividido entre as empresas. Cada poluidor passa a dispor de uma cota de gás que pode emitir. Incorporam-se novas tecnologias mais "limpas", a ponto de suas emissões ficarem abaixo da cota, podem vender seus créditos remanescentes para outros poluidores (que continuam com níveis de poluição acima da cota) ou mesmo para outras empresas que queiram se estabelecer no mesmo ramo. Os poluidores podem escolher qual caminho é mais vantajoso em termos de custo: despoluir e vender (as licenças), ou continuar a poluir e comprar.

Existem várias formas de regulamentar a comercialização das permissões de emissão negociáveis \{baseado em Almeida (1997) e Pearce (1985)\}:

- Política de compensação (offset policy) - em áreas consideradas "sujas" (por exemplo, aquelas onde a qualidade do ar não atende aos padrões ambientais) admite-se a entrada de novas empresas poluidoras ou expansão das antigas desde que adquiram permissões de emissão negociáveis de empresas já existentes na área, compensando as novas emissões com reduções ainda maiores nas fontes já existentes. Ou seja, em vez de impor uma lei de zoneamento rígida, barrando a expansão de atividades na área, permite-se o ingresso de novas empresas, uma vez que a qualidade ambiental local não seja prejudicada, mas melhorada;

- Política da bolha (bubble policy) - esta denominação é devido ao fato de tratar múltiplos pontos de emissão (que lançam o mesmo poluente) de uma planta poluidora existente em determinada área como se 
estivessem envoltos numa bolha. O que se controla é o total de emissões de cada poluente (por exemplo, dióxido de enxofre) lançado pela bolha. Enquanto este total estiver abaixo do total permitido (que resulta do somatório dos padrões de emissão de todos os pontos de descarga da bolha), alguns pontos de descarga podem não estar atingindo o padrão fixado, mas são compensados por permissões de emissão negociáveis de outros pontos mais "limpos". Dessa forma, os poluidores têm liberdade para montar a combinação de pontos de descarga "sujos" e "limpos" que melhor thes convier, desde que atendido o padrão de emissão total da bolha. Esta mesma política também pode ser aplicada a bolhas multiplantas, abrindo a possibilidade de comercialização de permissões de emissão negociáveis entre diferentes poluidores;

- Política de rede ou de emissão líquida (netting policy) - permite a empresas já existentes, que queiram promover alguma reestruturação ou expansão, escapar dos controles mais rigorosos que incidem sobre novas fontes poluidoras, desde que o aumento liquido das emissões (podendo descontar as permissões de emissão negociáveis obtidas em outros pontos da planta) seja compensado por uma redução em outras partes da planta. Esta política propriamente mais alivia o agente poluidor de uma regulamentação do que exerce efeitos regulatórios;

- Estoque de permissões (banking) - permite às empresas estocar permissões de emissão negociáveis, para uso futuro, nas políticas de compensação (offset policy), políticas da bolha (bubble policy), política de rede ou de emissão liquida (netting policy) ou vendê-los para terceiros.

A regulamentação da comercialização das permissões de emissão negociáveis envolve ainda o modo como são distribuídas no primeiro momento. Segundo Lanna (1996), a rigor, não interessaria o preço original de cada título - eles poderiam ser, inclusive, distribuídos gratuitamente entre aqueles agentes que tenham seus lançamentos previamente licenciados.

As vantagens da aplicação das permissões de emissão negociáveis:

- permite um controle direto do montante de poluição (que é fixado no momento inicial da distribuição das permissões). O padrão ambiental desejado é fixado em termos de quantidade (e não mediante a ajuste da taxa) que é uma grande vantagem principalmente numa estrutura de inflação e de entrada de novas fontes de poluição no mercado: com quantidade fixa de permissões, o preço deve aumentar para equilibrar o mercado como resultado do excesso de demanda;

- a concessão das permissões pode ser motivo de um leilão de tal forma que as fontes pagam pelo direito de poluir ou podem ser sim- 
plesmente distribuídos sem encargos às fontes existentes, as quais são livres para trocá-los ou vendê-los a novas fontes. A vantagem desta política é que o fato do poluidor deter a propriedade de um tal ativo de valor, muito provavelmente, deve gerar menos resistência do que a imposição de uma taxa;

- permite que organizações não-governamentais que tenham como objetivo "comprar" uma melhor qualidade ambiental, atinjam seu objetivo comprando uma parte destas permissões de emissão negociáveis e retirando-as do mercado. Esta alternativa também poderia ser adotada pelo poder público, sempre que notar que algum agente compra o títulos com objetivo puro e simples de impedir a concorrência e monopolizar o mercado de seu produto.

Entretanto a aplicação deste instrumento de política ambiental apresenta uma série de inconvenientes. Lambelet (1972) apud Pearce (1985) demonstrou que se algum poluidor pode influir sobre os preços das permissões, o preço não se relacionará com os custos marginais de controle de poluição da forma adequada. Ocorre a mesma situação se este mercado enfrenta um único poluidor (monopólio). Isto sugere, em parte, que o organismo controlador deve abranger uma área extensa para que o preço global das permissões fique governado pela demanda e pela oferta agregadas e não por ações de individuos fixadores de preços.

Um aspecto relevante em relação à aplicação deste instrumento é que ele não gera receitas e nesta época de déficit orçamentário em que os governos procuram novas fontes de receita, isto pode até se constituir em um fator determinante para a escolha do instrumento de política ambiental a ser utilizado. Oates (1991) apud Ramos (1996) menciona a criação de uma lei federal nos Estados Unidos, em 1987, que impôs uma taxa sobre emissões de óxido de nitrogênio e de enxofre. Esta taxa não foi proposta por uma instituição encarregada do meio ambiente, mas pela House Ways and Means Committee a fim de obter receitas para reduzir o déficit do orçamento federal.

Existem experiências na adoção desta política nos EUA, no controle da poluição do ar (The Clean Air Act - 1970), comentado por Pearce e Turner (1990), e na extração de ostras, na forma de Permissões de Extração de Recursos Negociáveis. Na Nova Zelândia e Austrália existe esta experiência no controle de pesca. Uma outra variação desta política é a concessão de Direitos de Desenvolvimento Transferíveis que possui uma aplicação relativamente recente na proteção de terras úmidas (wetlands) nos EUA, através do sistema de "estoque de mitigação" (Mitigation Banking). Este sistema consiste na criação, restauração ou aumento da proteção de uma área de wetlands funcional, para antecipar ou compensar a ocorrência de impactos em wetlands da mesma ecorregião. Dessa forma, o licenciamento 
de atividades que se desenvolvam em áreas de wetlands, pode ser condicionado à aquisição de "créditos de mitigação".

Os resultados no controle da poluição atmosféricas originadas em emissões industriais nos EUA ainda não foram os esperados, já que a maioria das transações ocorreu no âmbito dos conglomerados industriais, ou seja, pelo rearranjo das emissões entre as diversas unidades produtoras de uma mesma empresa industrial, detentora de uma certa quantidade de títulos, e não entre grupos industriais distintos. Segundo Lanna (1996), a causa é, possivelmente, os altos custos de aquisição de informação sobre a disposição de negociação de outras indústrias, o que envolveria a liberação de segredos industriais. O quadro abaixo apresenta um resumo da experiência americana no uso das permissões de emissão negociáveis, no controle da poluição do ar, no fim da década de 80 .

Quadro 4 - Experiência americana no uso das permissões de emissão negociáveis

\begin{tabular}{|c|c|c|c|c|c|}
\hline & \multicolumn{2}{|c|}{$\begin{array}{c}\text { Bolhas } \\
\text { (introd.: 1979) }\end{array}$} & $\begin{array}{l}\text { Compensação } \\
\text { (introd.: 1976) }\end{array}$ & $\begin{array}{c}\text { Redes } \\
\text { (introd.: 1974) }\end{array}$ & $\begin{array}{c}\text { Esfoque } \\
\text { (introd.: 1979) }\end{array}$ \\
\hline & Federal & Estadual & & & \\
\hline Número de transacões & 42 & 89 & 2000 & $5000-12000$ & $<120$ \\
\hline $\begin{array}{l}\text { Redução de } \\
\text { Custos (US\$ milhões) }\end{array}$ & 300 & 135 & Grande & $525-12300$ & Pequena \\
\hline $\begin{array}{l}\text { Impacto na } \\
\text { qualidade do ar }\end{array}$ & zero & zero & Zero & $\begin{array}{l}\text { Provavelmente } \\
\text { insignificante }\end{array}$ & $\begin{array}{c}\text { Provavelmente } \\
\text { insignificante }\end{array}$ \\
\hline $\begin{array}{l}\text { Natureza das transa- } \\
\text { ções }\end{array}$ & & & & & \\
\hline $\begin{array}{l}\text { Internas } \\
\text { Externas }\end{array}$ & $\begin{array}{r}40 \\
2\end{array}$ & $\begin{array}{c}89 \\
0\end{array}$ & $\begin{array}{l}1800 \\
200\end{array}$ & $5000-12000$ & $\begin{array}{l}<100 \\
<20 \\
\end{array}$ \\
\hline
\end{tabular}

Fonte: OECD (1994a) ${ }^{3}$

Finalmente, cabe frisar que as permissões negociáveis representam o mais liberal dos instrumentos econômicos de controle ambiental, pois apesar da interferência do governo no momento inicial da distribuição das cotas de emissão, a partir dai o poluidor tem flexibilidade para realizar ou não melhorias ambientais, não precisando inclusive contribuir para os cofres públicos, como ocorre com as taxas.

Para finalizar a apresentação dos instrumentos econômicos, é apresentada, a seguir, uma tabela-resumo destes instrumentos, baseada em uma lista de checagem elaborada pela OECD (1994a), contendo as possíveis circunstâncias sob as quais poderiam ser aplicados. Esta lista foi adaptada de uma versão anterior, para contemplar o contexto dos países em desenvolvimento.

${ }^{3}$ Baseado em Hahn, R. e Hester, G. (1989); e Hahn, R. (1987). 
Quadro 5 - Resumo de alguns instrumentos econômicos

Definição

Cobrança sobre a descarga de poluentes na atmosfera, água e solo.

Vantagens

- Reduz os custos de atendimento ao padrão

- Incentivo dinâmico à redução da poluição

- Aumento da arrecadação

- Flexibilidade de resposta

Aplicabilidade

- Principalmente para fontes estacionárias

- Os custos marginais de abatimento devem ser variáveis

- O monitoramento das emissões deve ser viável

Relevância em função do tipo de meio

- Água: alta - existe na França, Alemanha e Holanda

- Ar: Média a alta - é mais fácil onde as emissões são estimadas pelo consumo de combustivel

- Resíduos: média - existe para efluente tóxico nos EUA; efluente da criação de gado na Holanda

- Ruido: alta - aviões; baixa - automóveis

Questões

- Como alocar a arrecadação especifica

- Os efeitos distributivos são relevantes nos países desenvolvidos e em desenvolvimiento

- Pode ser necessário um monitoramento complexo, limitando a relevância da cobrança para paises em desenvolvimento, dependendo do estágio de desenvolvimento 
Definição

Cobrança sobre produtos com efeitos negativos sobre o meio ambiente.

Vantagens

- Estimula a redução no uso do produto, a substituição do produto e a redução de efluente na fonte

- Incentivo dinâmico à redução da poluição

- Aumento da arrecadação

- Pode substituir as cobranças por emissões

- Aplicável para fontes móveis e difusas

- Facilidade de implementação

- Flexibilidade

Aplicabilidade

- Onde o produto é usado em grandes quantidades

- Produtos facilmente identificáveis

- Alta elasticidade da demanda

- Necessidade de controlar fontes difusas

- Possibilidade de usar os canais fiscais e administrativos existentes

Relevância em função do tipo de meio

- Água: alta - cobrança sobre fertilizantes na Escandinávia; óleos lubrificantes na Alemanha

- Ar: alta - conteudo de enxofre dos combustiveis na França; preços diferenciados para gasolina com e sem chumbo, em vários países

- Resíduos: alta - reciclagem de vasilhames de bebidas, containers, etc

- Ruído: média - possivel taxação de veículos, em função dos níveis de ruido

Cobrança sobre Produtos

continuação

Questões

- Inaplicável onde as proibições são mais apropriadas (substâncias altamente tóxicas)

- Implicações sobre o comércio e a competitividade

- Problemas relacionados aos efeitos distributivos, principalmente em paises em desenvol-

vimento

\section{Permissōes Negociáveis}




\section{Definição}

Cotas de emissão ou de uso de recursos cujo total de cotas individuais igualam o padrão ambiental, sendo esta cotas negociáveis.

Vantagens

- Reduz os custos de controle

- Permite o crescimento econômico sem a redução da qualidade ambiental, uma vez que novos poluidores podem comprar as cotas dos poluidores existentes

- Flexibilidade

- Os "preços" da negociação podem variar, a fim de reduzir a poluição total. Ex: o preço de uma unidade incremental de poluição pode ser a redução de duas unidades em algum outro lugar

Aplicabilidade

- Melhor aplicado para fontes estacionárias

- Os custos de abatimento devem ser variáveis entre os poluidores

- Os custos de extração devem variar, se as cotas são aplicadas ao uso de recursos

- Deve haver um número significante de negociadores

- Potencial para inovação tecnológica

- O impacto ambiental deve ser independente da localização dos poluidores

- Mercados de intermediação asseguram um mercado funcional

Relevância em função do tipo de meio

- Água: baixa - os impactos ambientais dependem da localização da fonte

- Ar: alta - ver Quadro 4

- Residuos: baixa - os impactos ambientais dependem da localização da fonte

- Ruido: baixa - os impactos ambientais dependem da localização da fonte

\section{Questöes}

- Dificuldade de aplicação para mais de um poluente simultaneamente - é um problema para

o controle integrado da poluição

- Possiveis áreas criticas, pois as permissões podem ficar concentradas em uma determinada área

- Surgem ganhos econômicos que revertem para os poluidores, a menos que as permissões

sejam leiloadas

- Custos de transação potencialmente altos

- Dificil aplicação em paises em desenvolvimento, pela necessidade de um mercado relativamente sofisticado, mas pode ser bem utilizado, na forma de cotas de uso de recursos (pesca, por exemplo), onde existam órgãos regulamentadores.

Fonte: OECD (1994a)

\section{3 - Instrumentos econômicos versus comando e controle}

Uma questão que domina o debate internacional sobre política ambiental é sobre a superioridade de um ou de outro instrumento.

A defesa dos instrumentos econômicos é geralmente baseada na argumentação de que sua essência reside no funcionamento do mercado, permitindo simultaneamente a flexibilidade de resposta por parte dos agentes poluidores. Em contrapartida, sob políticas de comando e controle, do tipo prescrição tecnológica, o poluidor não tem alternativas, a não ser a adoção da tecnologia prescrita. Sob a ação de instrumentos econômicos, um custo pela poluição é imposto ao poluidor, que pode escolher a maneira mais eficiente de responder a este custo. Desta forma, seria incentivado o 
atendimento a padrões ambientais mediante a busca da eficiência econômica interna.

A possibilidade de redução dos custos totais de atendimento dos padrões estabelecidos, mediante a busca de uma eficiência econômica global, é outro argumento de defesa dos instrumentos econômicos. Como os custos de controle da poluição variam de um poluidor para outro, o controle da poluição deveria ser direcionado para os poluidores capazes de efetuá-lo com os menores custos.

Considere-se, por exemplo, dois poluidores A e B, com custos marginais de abatimento de $\$ 20$ e $\$ 40$ por metro cúbico de efluente tratado, respectivamente. Se, sob uma política de comando e controle, for exigido que cada um incremente o tratamento de seus efluentes em um metro cúbico, então o custo total de abatimento será de $\$ 60$, para um tratamento total de 2 metros cúbicos. O mesmo nivel de tratamento poderia seria obtido a um custo de $\$ 40$ se o poluidor $A$ tratasse 2 metros cúbicos e o poluidor $B$ nada tratasse. $O$ incentivo para que $A$ trate uma quantidade maior de efluente do que $B$ poderia ser tanto a aplicação de cobrança sobre as emissões, como uma cota de emissão negociável. Uma taxa de $\$ 30$ por metro cúbico de efluente não tratado incentivaria o poluidor $A$ a tratar todo seu efluente, pois seus custo marginal de tratamento (caso constante) seria inferior ao valor da taxa. O poluidor $B$, por ter um custo marginal de tratamento superior ao valor da taxa, iria optar pelo pagamento da taxa.

De forma análoga, para o caso de uso de quotas de emissão negociáveis, pode-se tomar os mesmos poluidores $A$ e $B$. Caso as cotas sejam distribuidas de tal forma que $A$ e $B$ necessitem aumentar seu nivel de tratamento em um metro cúbico cada um, o poluidor $B$, conhecendo seu custo marginal de abatimento de $\$ 40$ por metro cúbico de efluente tratado, estaria disposto a comprar uma permissão para este metro cúbico, desde que o preço desta fosse inferior a $\$ 40$. Por outro lado, o poluidor $A$ estaria disposto a tratar mais um metro cúbico, para compensar a venda de uma permissão, desde que o valor da venda fosse superior ao seu custo marginal de tratamento ou seja, superior a $\$ 20$. Nestas condições, pode-se esperar que ocorra a negociação e a conseqüente redução dos custos totais de tratamento.

Vários estudos simularam os efeitos da adoção de políticas baseadas em instrumentos econômicos para redução da poluição do ar em distintas localidades nos EUA. Para se atingir o mesmo padrão ambiental, esses estudos apontaram um diferencial de custo em média seis vezes superior ao das políticas de "comando e controle" em comparação às políticas de custo-mínimo (baseados em incentivos econômicos) (Almeida, 1997).

Estes estudos apresentam um problema que é a comparação feita entre políticas de "comando e controle" adotadas na prática e politicas ideali- 
zadas (não praticadas) de custo mínimo, sendo que os resultados são interpretados como ganhos potenciais da adoção de instrumentos econômicos, tais como licenças de poluição. Uma comparação mais realista deveria ser feita entre políticas de "comando e controle" e políticas baseadas em instrumentos econômicos (taxa, licenças, etc.) ambas já colocadas em prática. Dessa forma, as restrições politicas e as dificuldades práticas para a implantação de instrumentos econômicos deixariam de ser ignoradas por estudos que se valem de fatos altamente estilizados para comparações.

Os instrumentos econômicos, além da propriedade de eficiência econômica (solução de custo mínimo) que corresponde a uma vantagem no sentido estático apenas, proporcionam também incentivos econômicos para:

- reduções adicionais de poluição, desde que haja tecnologia disponível;

- desenvolvimento e introdução de novas tecnologias de controle da poluição.

No caso da aplicação de taxas, em função da dificuldade em determinar seu valor ótimo e no receio existente de que possam provocar um efeito negativo sobre a competitividade regional, sua determinação é geralmente feita através de uma negociação entre os setores envolvidos. Dessa forma, o valor estabelecido, em geral, não terá condições de incentivar a inovação tecnológica nos níveis teoricamente preconizados.

A aplicação de uma politica de controle ambiental demanda grandes investimentos do poder público voltados para a fiscalização. Principalmente nos paises mais pobres, com recursos financeiros mais escassos, isto agrava a impressão, à primeira vista, de que a escolha entre crescimento econômico ou proteção ambiental é claramente antagônica, gerando resistências e dificuldades e enfatizando a necessidade de se ter os menores custos de controle possiveis. A maioria dos autores indica que a aplicação dos instrumentos econômicos envolve menores custos, pela diminuição da necessidade de monitoramento sistemático da qualidade ambiental, adotando-se normalmente sistemas alternativos que envolvam automonitoramento dos agentes com fiscalização das agências responsáveis. De qualquer forma a necessidade de monitoramento continua.

\section{4 - A EXPERIÊNCIA COM POLÍTICA AMBIENTAL}

Muito embora ainda predominem com folga a utilização de instrumentos "comando e controle", estudos da OECD confirmam uma tendência de uso crescente de instrumentos econômicos na politica ambiental de seus paises membros. A explicação para a predominância dos instrumentos de "comando e controle" é, em parte, a eficácia ecológica apresentada pelos mesmos 
(a certeza dos efeitos da regulação sobre a qualidade ambiental), que garante amplo apoio da opinião pública, notadamente de grupos de ambientalistas, e que seguramente influenciam a tomada de decisão. Os decisores, por sua vez, estão mais familiarizados a este tipo de política, dada a experiência com a mesma em outras áreas de políticas públicas.

Outro aspecto importante é que os instrumentos de regulação parecem ser preferidos também pelos próprios poluidores. As empresas acreditam ter maior influência sobre as regulações por intermédio de acordos, negociações, algumas inclusive de caráter ilícito (suborno a fiscalizadores, por exemplo). Certas formas de regulação, como as licenças não comercializáveis, padrões de qualidade ambiental e zoneamento, podem operar como barreiras à entrada de novas empresas, favorecendo as empresas já estabelecidas no mercado que, por sinal, se esforçam por alegar que o meio ambiente já está sobrecarregado de poluidores. Além disso, instrumentos econômicos como as taxas representariam adições aos custos da produção mais "limpa", a qual as empresas são induzidas a implementar.

A decisão pela adoção ou não de instrumentos econômicos passa por preocupações e avaliações econômicas, científicas e políticas. Neste sentido, os potenciais impactos do uso dos instrumentos econômicos, sobre determinadas classes de renda, ou setores de atividade, representam um aspecto-chave a ser considerado. A avaliação das conseqüências distributivas sobre grupos de renda baixa é um exemplo. A OECD (1994b) aponta duas questões que ilustram a complexidade da análise dos efeitos distributivos dos instrumentos econômicos e cujo esclarecimento é fundamental, para que se obtenha um cenário adequadamente informado sobre as conseqüências da aplicação destes instrumentos:

- Quem são os beneficiados (ganhadores) e quem são os prejudicados (perdedores), no caso de implementação de instrumentos econômi$\cos$ ?

- Caso ocorram efeitos negativos, quais são as medidas capazes de atenuá-los?

Almeida (1997) destaca que um forte argumento levantado a favor das taxas ambientais é que estas poderiam ser adotadas em meio a uma reforma mais ampla: uma "reforma tributária verde", em que fossem reduzidos os impostos sobre a renda (em especial sobre os rendimentos do trabalho) e sobre produtos/atividades "ambientalmente corretas" e elevados os impostos sobre as atividades que a sociedade deseja desestimular ("ambientalmente agressivas").

Esta troca parece muito atraente, embora exista uma dificuldade de convencer as pessoas a pagarem por algo que antes usufruiam gratuitamente. Acredita-se que essas pessoas fariam oposição a este tipo de pa- 
gamento devido à suspeita de que teriam que simplesmente arcar com mais impostos sem se beneficiarem da redução de outros.

No que diz respeito à classe trabalhadora, esta suspeita é, de certo modo, procedente, conforme ilustra os dados disponiveis sobre a evolução de impostos totais na UE no período 1980-1993 (Almeida, 1997):

- Impostos sobre o trabalho - constituem a principal fonte de taxação (em torno de $50 \%$ ) e esta parcela permaneceu estável no período;

- Impostos sobre o capital - constituem a segunda maior fonte de taxação (aproximadamente $20 \%$ ), porém esta parcela foi decrescente no periodo;

- Impostos sobre energia e as demais taxas ambientais - são relativamente pequenos em 1993 (5,2\% e 1,5\% respectivamente), porém esta parcela foi crescente no período.

Uma análise geral sobre a difusão das taxas ambientais na UE sugere que as "reformas tributárias verdes" estariam apenas no início nesta década de 90.

$\mathrm{Na}$ década de 70, predominaram as experiências dos paises avançados com as taxas ambientais sobre os usuários, inicialmente consistindo em pagamentos pelos custos de tratamento de efluentes incluindo, em seguida, os pagamentos destinados a algum propósito ambiental (por exemplo, serviço de reciclagem), mas ainda não na forma de um serviço específico oferecido ao usuário-pagador.

Na década de 80, a ênfase era nas taxas com o propósito de incentivo a melhorias ambientais por parte do agente agressor do meio ambiente. No início da década de 90 , as atenções se voltaram para as taxas com propósitos fiscais, isto é, de geração de receitas destinadas a fins ambientais e, até mesmo, outros. Acredita-se que a tendência seja aprofundar o uso destas taxas ambientais com objetivos fiscais em direção a uma proposta mais radical de "reforma tributária verde", que deverá constituir o cenário provável para a próxima década.

\section{5 - POLÍTICA AMBIENTAL BRASILEIRA}

Em relação ao debate internacional sobre a aplicação de politicas ambientais, não há dúvida de que o Brasil está atrasado, entretanto este fato não resulta unicamente em desvantagem. O Brasil pode se beneficiar deste atraso, oferecendo soluções criativas e apropriadas às nossas condições especificas.

Evidentemente, a maior desvantagem é a possibilidade de ceder à tentação de reproduzir aqui propostas de políticas ambientais, defendidas com veemência por economistas entusiasmados com modelos econômicos padrões e recomendados por organizações multilaterais (OECD, Banco 
Mundial e BID), mas ainda pouco difundidas naqueles países que dispõem de uma capacidade institucional mais adequada a esta orientação politica, do que a que se apresenta no Brasil.

Outro risco que também deve ser considerado é a possibilidade de, principalmente, países desenvolvidos utilizarem de critérios ambientais, sob o pretexto de defender o meio ambiente, para protegerem seus interesses comerciais.

O Brasil, apesar de não ter uma tradição na área de gestão ambiental, tem um arcabouço legal que data da década de 30 . Este corpo legal está passando por uma fase de modernização que iniciou com a constituição de 1988 e tem como ponto alto a sanção presidencial na lei 9433/97, que institui a Política Nacional de Recursos Hídricos e cria o Sistema Nacional de Gerenciamento de Recursos Hídricos. A aprovação desta lei confirma uma tendência mundial de utilização de instrumentos econômicos, apesar de que ainda assim a predominância seja a utilização de instrumentos do tipo "comando e controle".

A Lei $9433 / 97$ estabelece que os usos da água devem ser tarifados e estes valores deverão ser definidos no âmbito de cada bacia hidrográfica. $A$ conseqüência imediata é a possibilidade de haver variações dos preços cobrados não só entre os Estados mas também entre pontos diferentes no interior deste próprio Estado.

Nos últimos anos, tem sido noticiada com boa freqüência na imprensa a "guerra fiscal" travada entre os Estados, no qual cada um tenta oferecer o maior número de vantagens para os grandes investimentos, como forma de atraí-los para o interior de suas fronteiras, entre estas vantagens, cita-se várias formas de subsídios.

Estendendo esta mesma lógica para uma situação onde a cobrança pelos usos da água já estiver em pleno funcionamento, o preço que cada Estado fixar para a água poderá ter um peso tão importante quanto as vantagens fiscais para a decisão do investidor. Segundo Amanhã (1997), os últimos grandes investimentos anunciados no Brasil, puxados pelas montadoras de veículos, deixaram claro que não só vantagens fiscais, mas também disponibilidade de recursos hídricos pesam na decisão.

\section{CONCLUSÃO}

A necessidade de gestão das águas se torna evidente ao analisarmos o crescimento rápido da demanda, ancorada pelo crescimento populacional e o desenvolvimento econômico e, em algumas regiões, agravados por fatores climáticos. Esta gestão ambiental pode ser feita com a utilização dos instrumentos do tipo "comando e controle" e os ditos instrumentos econômicos. Cada grupo de instrumentos tem seus críticos e seus defensores, no 
entanto, este impasse vem sendo superado na prática com a experiência internacional que tem combinado ambas medidas de política ambiental.

Embora os instrumentos econômicos continuem altamente propalados no debate internacional, entre outras razões pela possibilidade de gerar receita de uma forma mais transparente, nunca é demais lembrar os impactos que sua aplicação pode causar: impactos sobre os preços agregados, distribuição de renda, emprego e comércio, etc. Novamente, os instrumentos de "comando e controle" também podem exercer estes impactos. Isto reforça a importância de se estudar todos os possiveis efeitos de um determinado instrumento (micro- e macroeconômico) previamente à sua introdução, bem como de realizar uma avaliação sistemática dos seus resultados.

Outro aspecto que amplia a importância da avaliação de cada instrumento de gestão ambiental é relacionado à discussão da competitividade internacional e regional.

$\mathrm{Na}$ atual conjuntura econômica de mercados globalizados, a batalha por "fatias de mercados" envolve não somente empresas de diferentes países, mas também distintos sistemas de mercado que influenciam diferenciadamente a capacidade de concorrer das suas empresás. Em outras palavras, isto dá a dimensão sistêmica da competitividade. As vantagens oferecidas pelo ambiente extra-empresa, em especial, às práticas institucionais e políticas nacionais, ganham importância maior neste contexto. Na verdade, a concorrência entre empresas é também uma concorrência entre sistemas, havendo, portanto, pouca tolerância para divergências sistêmicas.

Finalmente, a necessidade de aplicação de política de gestão ambiental é evidente e o desafio é, entre outros, compreender como se relacionam os instrumentos de política ambiental com a questão da competitividade e ainda mais como assegurar a proteção do meio ambiente sem comprometer o desenvolvimento econômico.

\section{BIBLIOGRAFIA}

AMANHÃ. 1997. A Commodity do Século 21. Porto Alegre, jan, p 42-55.

ALMEIDA, $L$. T. O debate internacional sobre instrumentos de política ambiental e questões para o Brasil. In: I/ Encontro Nacional da Sociedade Brasileira de Economia Ecológica, São Paulo, 1997, p 3-21.

AMARAL, C. A. F. Recursos naturais, economias de escala e as conseqüências da liberalização comercial. In: II Encontro Nacional da Sociedade Brasileira de Economia Ecológica, São Paulo, 1997, p. 96-116. 
CÁNEPA, E. M. 1995. Economia do meio ambiente. In: Introdução a economia. São Paulo: Atlas: cap 16, p. 413-438.

KEMPER, K. E. 1997. O custo da água gratuita - alocação e uso dos recursos hídricos no Vale do Curü, Ceará, Nordeste Brasileiro. Linköping: Linköping Studies in Arts and Sciences, 248p.

LANDES, D. S. Riqueza e a pobreza das nações. Rio de Janeiro: Editora Campus 1998, $960 p$.

LANNA, A. E. Instrumentos econômicos de gerenciamento ambiental. Porto Alegre: Instituto de Pesquisas Hidráulicas da UFRGS, 1996. [notas de aulas].

LEAL, M. S. Gestão ambiental de recursos hidricos por bacias hidrográficas: sugestões para o modelo brasileiro. Rio de Janeiro: UFRJ - Curso de Pós-Graduação em Engenharia, 1997. Dissertação (Mestrado em Engenharia Civil).

MARTINEZ JR., F. \& BRAGA JR., B.P.F. Aplicação de instrumentos econômicos à gestão ambiental: o caso dos recursos hidricos. In: Anais XII Simpósio Brasileiro de Recursos Hidricos. ABRH, Vitória, v. 1, p.25-32, 1997.

MAY, P. H. e BONILLA, O. S. The environmental effects of agricultural trade liberalization in Latin America: an interpretation. Ecological Economics, v. 22, n. 1, p. 5-18, 1997.

OECD. Project and policy appraisal: integrating economics and environment. Organisation for Economic co-operation and Development. Paris, 1994a, 346p.

OECD. The distributive effects of economic instruments for environmental policy. Organisation for Economic Co-operation and Development. Paris, 1994b, 159 p.

OFFICE INTERNATIONAL DE L'EAU. La gestion del agua por cuenca vertente. In: Modulo de formacion multimedia. Rio de Janeiro, 1995, 220p.

PEARCE, D. W. Economia ambiental. México: Fundo de cultura econômica, 1985, 258p.

PEARCE, D. W.; TURNER, R. K. Economics of natural resources and the environment. Londres: Harvest Wheatsheat, 1990, 378p.

PEREIRA, J. S. Análise de critérios de outorga e de cobrança pelo uso da água na Bacia do Rio dos Sinos. Porto Alegre: UFRGS - Curso de Pós-Graduação em Recursos Hídricos e Saneamento, 1996. Dissertação (Mestrado em Engenharia Civil).

PRIMO BRAGA, C. A. 1992. Tropical forest and trade policy: The case of Indonesia and Brazil. In: LOE, P. (ed). International trade and environment. World Bank discussion paper, 159

RAMOS, F. S. Qualidade do Meio Ambiente e Falhas de Mercado. Análise Econômica. Porto Alegre: FCE/UFRGS, ano 14, $\mathrm{n}_{\mathrm{s}} 25$ e 26, p. 34-35, mar. e set., 1996.

SOUZA, Nali de Jesus de Desenvolvimento econômico. São Paulo: Atlas, 1997.

UNCED. 1992. Agenda 21: Chapter 18. United Nations conference on environment. New York: United Nations.

WORLD BANK. 1993. Water resources management: A World Bank policy paper. Washington, D.C.: The World Bank.

HAHN, R. e HESTER, G. Where did all the markets go? an analysis of EPA's Emissions Trading Program. Yale Journal of Regulation, v. 6, n. 1, p. 109-153, winter 1989.

HAHN, R. The market for bads: EPA's experience with emissions trading. Regulation, $\mathrm{n}$. $3 / 4,1987$. 